\title{
ANTINOCICEPTIVE AND ANTIANXIETY ACTIVITY OF HYDROETHANOLIC EXTRACTS OF THREE IMPATIENS SPECIES IN MICE
}

\author{
KATARZYNA SZEWCZYK ${ }^{*}$, JOLANTA ORZELSKA-GÓRKA², MAGDALENA POLAKOWSKA² \\ and GRAŻYNA BIAŁA ${ }^{2}$
}

${ }^{1}$ Chair and Department of Pharmaceutical Botany, Medical University of Lublin, Lublin, Poland ${ }^{2}$ Chair and Department of Pharmacology and Pharmacodynamics, Medical University of Lublin, Lublin, Poland

\begin{abstract}
The plants of the Impatiens L. (Balsaminaceae) have been used for a long time in folk medicine in different painful conditions, and to treat rheumatism, isthmus and crural aches, fractures, superficial infections, fingernail inflammation. This study was undertaken to determine the pharmacological profile of hydroethanolic extracts from Impatiens glandulifera, I. noli-tangere and I. parviflora. A range of behavioral assessments was applied to evaluate the effects of obtained extracts i.e. measurement of body temperature, tests of locomotor activity and motor coordination, nociceptive reaction and anxiety-like behavior. Hydroethanolic extracts were analyzed for total polyphenol (TPC), flavonoid (TFC), flavones/flavonols (TFFC), and flavonones/dihydroflavonols (TFDC) content. Our results show that the extracts from Impatiens species contain high levels of TPC, TFC, TFFC, and TFDC. Oral (i.e., by gavage) administration of Impatiens L. extracts (except for I. nolitangere) presented an antinociceptive or/and anti-inflammatory activity in the writhing test. The antinociceptive effect of $I$. parviflora leaves $(100 \mathrm{mg} / \mathrm{kg})$ and $I$. glandulifera flowers $(100 \mathrm{mg} / \mathrm{kg})$ was reversed by naloxone. $I$. glandulifera flowers and roots extracts $(100 \mathrm{mg} / \mathrm{kg})$ increased the reaction time to the thermal stimulus in the hot-plate test. All extracts from I. glandulifera $(100 \mathrm{mg} / \mathrm{kg})$ showed antianxiety effect in the elevated plus-maze test. It is worth noting that none of the extracts, at the highest used dose $-0.1 \mathrm{ED}_{50}(200 \mathrm{mg} / \mathrm{kg})$, caused coordination impairments or myorelaxation as measured in the rota-rod and chimney tests. These results seem to suggest that the tested extracts are not neurotoxic. These findings show the potential use of hydroethanolic extracts from different parts of I. glandulifera as phytomedicine.
\end{abstract}

Keywords: CNS screening; antinociception; antianxiety; mice; Impatiens; Balsaminaceae

In accordance with the International Association for the Study of Pain (IASP), pain is defined as an unpleasant sensory and emotional experience caused by existing or potential tissue or organ damages or describes in terms of such damage (1). Many patients, who suffer for intense, especially chronic pain, have to depend on opioid analgesics, despite their well-known side effects, such as respiratory depression, constipation, and addiction (2). Therefore, the search for new compounds with a large spectrum of biological activities is very important. Plants are one of the potential sources for new drugs. It is estimated that about $50 \%$ of available drugs are derived from compounds first identified/isolated from plants, including also insects and animals, as active ingredients (3).

The Impatiens L. species occur in tropical and subtropical climate zones, mainly in parts of the Old
World such as tropical Africa, India, and the southwestern part of Asia, southern China. Some species were also found in Japan, Northern Europe, Russia, and North America (4). Impatiens glandulifera Royle (Himalayan balsam), I. noli-tangere L. (touch-me-not balsam) and I. parviflora DC. (small balsam), occur especially in the North-Western and Central Europe (5), North America (4) and New Zealand (6). They are annual herbaceous plants of the Balsaminaceae family (7). I. glandulifera and I. parviflora are among the invasive plants originally native to Asia that is rapidly spreading across Europe. In Poland, these are two of the top 20 invasive alien plants (8).

Among the members of the genus Impatiens L., some species have been used since a very long time in Asian and American medicine (9-11). The majority of phytochemical studies on the genus

\footnotetext{
* Corresponding author: e-mail:k.szewczyk@umlub.pl
} 
Impatiens focused on I. balsamina, because it has been applied in Chinese traditional medicine to treat many medicinal problems, i.e. rheumatism, fractures, swelling, contusions and beriberi disease (12). It has been also used to alleviate parturient and puerperal pain (13). Moreover, there is an in vivo study which has proven antinociceptive activity of methanol extract of its flowers (9). I. parviflora has been used in the treatment of warts (14). Flowers of I. glandulifera are used in Bach flower remedies, which cause sedation, relax and help to balance the emotional state, and they are recommended for psychological problems and pain (15). The roots and leaves of the plant are traditionally used in India as cooling agents, and the leaves decoction is used as a tonic in stress and mental tension (10). I. noli-tangere L. has been used in the Beskid in Poland to treat susto, a folk illness whose symptoms are: sleep disturbance, irritability, weakness, depression and muscle tension $(16,17)$. In our previous studies, we confirmed that the extracts from species of Impatiens contained significant amounts of phenolic acids and flavonoids, and have interesting multidirectional biological activity, such as antimicrobial and antioxidant abilities $(18,19)$. The LC-ESI-MS/MS analyses allowed identifying phenolic acids in extracts from the leaves, flowers, and roots of I. glandulifera, and from the leaves of I. noli-tangere and I. parviflora (20). Moreover, the results of UHPLC-DAD$\mathrm{MS}^{3}$ analyses revealed the presence of flavonoids in these species, especially kaempferol and quercetin derivatives with proven antinociceptive properties (18). We also showed the chemical composition of the essential oils obtained from four Impatiens species, Impatiens glandulifera Royle, I. parviflora DC., I. balsamina L. and I. noli-tangere L. and their antioxidant activities (21).

Based on the above phytochemical analyses, the use in folk medicine and in vitro studies indicating a putative biological action of different extracts from Impatiens glandulifera, I. noli-tangere and I. parviflora, the aim of the present study was to evaluate their pharmacological profile. Thus, a range of behavioral assessments was applied to evaluate the effects of extracts from flowers, leaves, and roots of I. glandulifera, and for comparison leaves extracts of I. noli-tangere and I. parviflora. Body temperature, locomotor activity, motor coordination, anxiety-like behavior and nociceptive reaction were examined. The nociceptive reaction is the time lapse between the beginning of the application of a stimulus, e.g. heat and the evoked response, e.g. to lift the hind paws. These measurements provide generallyaccepted assessments of behavior in investigations of bioactivity of new compounds (22). It is essential to characterize pharmacological activity of unknown substances in animal models because it is not possible to replicate the complexity of the organ systems, especially, the central nervous system in vitro. Such efforts are expected to provide meaningful data about the response of a biological system to new compounds.

\section{MATERIALS AND METHODS}

\section{Plant materials}

The plants were collected during July - August 2014. Impatiens glandulifera Royle (no. IG-0814) and I. noli-tangere L. (no. INT-0814) were gathered in Józefów near Biłgoraj (Poland) at an altitude of 240 m a.m.s.l. (coordinates N 50'29'06''; E 2302'12' ' and N 52 $57^{\prime} 58^{\prime}$ '; E 230.4'46', respectively). Impatiens parviflora DC. (no. IP-0814) was collected in Lublin (Poland) at an altitude of $210 \mathrm{~m}$ a.m.s.1. (coordinates N 5116'24', E 22'30'2'"). Voucher specimens were deposited in the Department of Pharmaceutical Botany, Faculty of Pharmacy, Medical University of Lublin. Plants were identified by Prof. Tadeusz Krzaczek.

\section{Extraction method}

Air-dried leaves, flowers and roots of I. glandulifera, and leaves of I. noli-tangere and I. parviflo$\mathrm{ra}$, were ground to a fine powder using a laboratory mill, and sieved. $100 \mathrm{~g}$ of each powdered samples was weighted accurately and extracted with sonicated with a mixture of ethanol/water $(8 / 2, v / v ; 3 \mathrm{x}$ $1000 \mathrm{~mL})$ at a controlled temperature $\left(40 \pm 2^{\circ} \mathrm{C}\right)$ for $30 \mathrm{~min}$. Supernatants were filtered and concentrated to dryness under vacuum at controlled temperature, and then subjected to lyophilization using vacuum concentrator until constant weights were obtained. Dry extracts were weighted and stored in a freezer at $-20^{\circ} \mathrm{C}$. The obtained yields: I. glandulifera flowers 21.90 g; I. glandulifera leaves - 20.91 g; I. glandulifera roots $-11.53 \mathrm{~g}$; I. noli-tangere $-10.75 \mathrm{~g} ;$ I. parviflora $-11.68 \mathrm{~g}$. The obtained samples were redissolved in the appropriate solvents for each determination.

\section{Total polyphenol content (TPC)}

The amount of total phenolics was determined using the colorimetric method with some modifications (23). The absorbance was measured at $660 \mathrm{~nm}$ (Spectrophotometer UV-VIS, Evolution 300, Thermo-Finnigan, Italy). The results were expressed as $\mathrm{mg}$ of gallic acid equivalent (GAE) per $1 \mathrm{~g}$ of dry weight (DW). 


\section{Total flavonoid content (TFC)}

Total flavonoids were evaluated according to the method described by Lamaison and Carret (24). The absorbance was measured at $394 \mathrm{~nm}$. Finally, the total flavonoid content was expressed as mg of quercetin equivalent (QE) per $1 \mathrm{~g}$ of $\mathrm{DW}$.

\section{Total phenolic acids content (TPAC)}

Total phenolic acids content was determined by the spectrophotometric method with Arnov's reagent according to the procedure described in Polish Pharmacopoeia IX (official translation of PhEur) (25). The absorbance was measured at 490 $\mathrm{nm}$, and the percentage of phenolic acids, expressed as caffeic acid equivalents (CAE) on DW, was calculated according to the formula: A $\times 1.7544 / \mathrm{m}$, where $\mathrm{A}$ - the absorbance of the test solution at 490 $\mathrm{nm}, \mathrm{m}$ - mass of the powdered plant material, in grams.

\section{Total flavones and flavonols content (TFFC)}

The total flavone and flavonol contents of the Impatiens samples were determined using aluminum chloride, according to the method described previously $(26,27)$. The absorbance was measured at $394 \mathrm{~nm}$. The results were expressed as $\mathrm{mg}$ of quercetin equivalent (QE) per $1 \mathrm{~g}$ of $\mathrm{DW}$.

\section{Total flavonones and dihydroflavonols content (TFDC)}

The flavonone and dihydroflavonol contents were determined using dinitrophenylhydrazine method with some modifications $(27,28)$. The absorbance of the supernatant solution was measured at $486 \mathrm{~nm}$ and the results were expressed as $\mathrm{mg}$ of eriodictyol equivalent (EE) per $1 \mathrm{~g}$ of DW.

\section{Animals}

The experiments were performed on male Albino Swiss mice (20-25 g), where 8 animals were kept in a cage, at room temperature of $22 \pm 1{ }^{\circ} \mathrm{C}$, with free access to food and water. All behavioral experiments were carried out according to the European Community Council Directive for Care and Use of Laboratory Animals (2010/63/EU) (29) and approved by the Local Ethics Committee for Animal Experimentation.

\section{Drug administration}

All extracts were administered intragastrically (i.g.), 60 min before the tests, dissolved in DMSO (its final concentration of $0.1 \%$ ), suspended in $0.5 \%$ Tween-80 (1-2 drops) and then diluted with saline solution $(0.9 \% \mathrm{NaCl})$. Naloxone $(\mathrm{Nx})$, purchased from Sigma Chemicals (St. Louis, USA) was administered subcutaneously (s.c.). Morphine was obtained from Sigma Chemicals (St. Louis, USA) and administered intraperitoneally (i.p.). In 'writhing' procedure, the acetic acid $(0.6 \%$ solution; Avantor Performance Materials Poland S.A.; formerly POCH S.A.) and metamizole (Pyralgin ${ }^{\circledR}$, Polpharma, Poland) were administered i.p. All solutions were given in a volume of $0.1 \mathrm{~mL}$ per $10 \mathrm{~g}$ body mass. Control animals were administered a corresponding vehicle.

\section{Oral acute toxicity test}

Acute toxicity assay was performed as per Organization of Economic and Corporation Development (OECD) guidelines 425 (Up-and-Down Procedure) with some modification (30). First animal received extracts orally at a dose of $500 \mathrm{mg} / \mathrm{kg}$, i.e. at the level of the best estimation of the median effective dose $\left(E D_{50}\right)$, calculated as "the loss of righting reflex" after $24 \mathrm{~h}$. The righting reflex is considered lost when a mouse, placed on its back, cannot move the head or body. Depending on the outcome for the previous animal, the dose for the next animal was adjusted up or down. If an animal did not show any signs of the loss of righting reflex, the dose for the next animal was increased (1000 $\mathrm{mg} / \mathrm{kg}$ ); if it lost the righting reflex, the dose for the next animal was decreased $(250 \mathrm{mg} / \mathrm{kg})$. The $\mathrm{ED}_{50}$ is calculated using the method of maximum likelihood. Doses should not exceed $2000 \mathrm{mg} / \mathrm{kg}$ which is considered the upper limit dose.

\section{Spontaneous locomotor activity}

Spontaneous locomotor activity was measured using an animal actometer Opto-Varimex-4 AutoTrack (Columbus Instruments, OH, USA). The device consists of four transparent cages with a lid $(43 \times 43 \times 32 \mathrm{~cm})$, a set of four infrared emitters (each emitter has 16 laser beams), and four detectors monitoring animal movements. Each mouse was placed individually into the cage for $30 \mathrm{~min}$. A number of break beams of a tested mouse was measured after 2, 4, 6, 10, 20 and $30 \mathrm{~min}$ to characterize dynamics of changes. The cages were cleaned up with $70 \%$ ethanol after each mouse (31).

\section{Motor coordination}

The effects of Impatiens L. extracts on motor coordination was evaluated in the rota-rod and chimney tests $(22,31)$. In the first test, motor impairments were measured, defined as the inability to keep balance on a rotating rod (at constant speed of $18 \mathrm{rpm}$ ) for $1 \mathrm{~min}$. In the second test, motor 
impairments were assessed by mouse inability to climb up the tube backwards $(3 \mathrm{~cm}$ in inner diameter, $25 \mathrm{~cm}$ long) within $60 \mathrm{~s}$. Before the tests, the animals were trained once a day for 3 days. The animals, able to stay on the rotating rod or to leave the chimney for $60 \mathrm{~s}$, were approved for experiments.

\section{Effects on body temperature}

Body temperature in normothermic mice was measured in animal's rectum with a thermistor thermometer during a total period of $180 \mathrm{~min}(60 \mathrm{~min}$ before and $120 \mathrm{~min}$ after tested compound injection). The mean value from the first two measurements (60 and 30 min before drug administration) was assumed as initial temperature (ti). The final temperature $(\mathrm{tf})$ was measured 30, 60, 90 and 120 min after the administration of tested extracts. Body temperature changes $(\Delta t)$ were calculated according to the formula: $\Delta \mathrm{t}=\mathrm{tf}-\mathrm{ti}(32)$.

\section{Acetic acid-induced writhing test}

Nociceptive reactions were studied in the acetic acid-induced writhing test (22). The mice were administered with extracts or metamizole and then the writhing was induced by $0.6 \%$ acetic acid solution. The number of writhing episodes was measured for $10 \mathrm{~min}$, starting $5 \mathrm{~min}$ after i.p. administration of $0.6 \%$ acetic acid solution. The contraction of the abdomen, elongation of the body, twisting of the trunk and/or pelvis ending with the extension of the limbs were considered as complete writhing. The influence of $\mathrm{Nx}(5 \mathrm{mg} / \mathrm{kg}$, s.c.; $30 \mathrm{~min}$ before the test) on the antinociceptive effect of the extracts was assessed according to the same procedure.

\section{Hot-plate test}

In this test, mice were individually placed on a hot plate (Ugo Basile, Italy) with adjustable temperature (to $55 \pm 1^{\circ} \mathrm{C}$ ). The response in the form of lifting either of the hind paws or a jumping with all four feet off of the hot-plate was recorded at $30 \mathrm{~min}$ time intervals up to $120 \mathrm{~min}$ after drugs injection. The baseline latency response before administration of a compound was first measured. The cut off time for the hot plate latencies was set at $20 \mathrm{~s}$. Animals were administered with extracts or morphine, according to the experimental paradigm. The antinociceptive effects of morphine and extracts were expressed as a percent maximum possible effect (\%MPE), which was calculated according to the following equation: $[(\mathrm{T} 1-\mathrm{T} 0) /(20-\mathrm{T} 0)] \times 100$, where $\mathrm{T} 0$ and $\mathrm{T} 1$ are the pre-drug and post-drug latencies for hot-plate response, respectively (33).

\section{Elevated plus-maze test (EPM)}

The EPM studies were carried out on mice according to the method of Lister (34). The EPM apparatus was made of Plexiglas and consisted of two open $(30 \times 5 \mathrm{~cm})$ and two enclosed $(30 \times 5 \times 15$ $\mathrm{cm})$ arms. The arms extended from a central platform of $5 \times 5 \mathrm{~cm}$. The apparatus was mounted on a Plexiglas base, raising it $38.5 \mathrm{~cm}$ above the floor, and illuminated by a red light. The test consisted of placing a mouse in the center of the apparatus (facing an open arm) and allowing it to freely explore. The number of entries into the open arms and the time spent in these arms were scored for a 5 min test period. An entry was defined as placing all four paws within the boundaries of the arm. The following measures were obtained from the test: the total number of arm entries; the percentage of arm entries into the open arms; and the time spent in the open arms expressed as a percentage of the time spent in both the open and closed arms. Anxiolytic activity was indicated by an increase in the time spent in open arms and in the number of open arm entries. The total number of entries into either type of arm was used additionally as a measure of overall motor activity.

\section{Statistical analysis}

The results were calculated by the two-way analysis of variance (ANOVA) (body temperature and hot-plate test) and one-way ANOVA (other tests), followed by the Dunnett's or Bonferroni's post hoc test as appropriate. The results are presented as means \pm standard errors of means (S.E.M). The level of $\mathrm{p}<0.05$ was considered statistically significant. All figures were prepared by the GraphPad Prism version 5.00 for Windows, GraphPad Software (San Diego, California, USA), www.graphpad.com.

\section{RESULTS}

\section{Polyphenols content}

The total phenolic contents expressed as gallic acid equivalents for Impatiens extracts were in the range from $13.26 \pm 1.68$ to $24.72 \pm 1.91 \mathrm{mg} \mathrm{GAE} / \mathrm{g}$ DW. The highest TPC content was found in extract from I. glandulifera flowers $(24.72 \pm 1.91)$, I. glandulifera leaves $(22.84 \pm 2.12)$, and I. parviflora leaves $(19.34 \pm 0.57)$. The highest content of phenolic acids was found in samples of $I$. noli-tangere leaves $(4.67 \pm 1.28 \mathrm{mg} \mathrm{CAE} / \mathrm{g} \mathrm{DW})$ and I. glandulifera flowers $(4.39 \pm 1.91 \mathrm{mg} \mathrm{CAE} / \mathrm{g} \mathrm{DW})$. The content of flavones and flavonols was higher than flavanones and dihydroflavonols content in all 
examined samples. High amounts of TFFC and TFDC were observed in I. glandulifera leaves (5.34 $\pm 0.29 \mathrm{mg} \mathrm{QE} / \mathrm{g} \mathrm{DW}$ and $4.72 \pm 1.83 \mathrm{mg} \mathrm{EE} / \mathrm{g} \mathrm{DW}$, respectively) (Table 1 ).

\section{Acute toxicity of Impatiens L. extracts}

Administration of Impatiens L. extracts at the doses 500-2000 mg/kg, i.g., did not cause any behavioral changes. Therefore, it has been calculated that the $\mathrm{ED}_{50}$ for Impatiens L. extracts is 2000 $\mathrm{mg} / \mathrm{kg}$ and the starting dose for behavioral tests was equivalent to $0.1 \mathrm{ED}_{50}$.

Effects of Impatiens L. extracts on the motor activity of mice

One-way ANOVA showed no significant changes in the locomotor activity of mice in all tested points. Whereas, Dunnett's post hoc test indicat- ed a significant decrease in locomotion of mice after the administration of the extract from I. glandulifera roots at the dose of $200 \mathrm{mg} / \mathrm{kg}$ in $30 \mathrm{~min}$ of measurement as compared to the control group $(\mathrm{p}<0.05)$ (Fig. 1).

\section{Effects of Impatiens L. extracts on the motor coor- dination of mice}

One-way ANOVA showed no significant changes in motor coordination of mice in both tests - the rota-rod and chimney test (Figs. 2A and 2B).

\section{Effects of Impatiens L. extracts on the body tem-} perature of mice

Two-way ANOVA showed statistically significant effects of the extracts $\left(\mathrm{F}_{(5,158)}=18.95 ; \mathrm{p}<\right.$ $0.0001)$ and time $\left(\mathrm{F}_{(3,158)}=4.04 ; \mathrm{p}<0.01\right)$. Bonferroni's post hoc test revealed a significant

Table 1. Total phenolic (TPC), phenolic acids (TPAC), flavonoids (TFC), flavones/flavonols (TFFC) and flavonones/dihydroflavonols content (TFDC) in examined plants expressed as mg GAE, mg CAE, mg QE or mg EE per $1 \mathrm{~g}$ of dry plant material, respectively. Results are means \pm SD of three different experiments.

\begin{tabular}{|c|c|c|c|c|c|}
\hline Sample & $\begin{array}{c}\text { Total phenolic } \\
\text { content } \\
\text { [mg GAE/g DW] }\end{array}$ & $\begin{array}{c}\text { Total phenolic } \\
\text { acids } \\
\text { [mg CAE/g DW] }\end{array}$ & $\begin{array}{c}\text { Total flavonoid } \\
\text { content } \\
\text { [mg QE/g DW] }\end{array}$ & $\begin{array}{c}\text { Total flavones and } \\
\text { flavonols content } \\
\text { [mg QE/g DW] }\end{array}$ & $\begin{array}{c}\text { Total flavonones } \\
\text { and droflavonols } \\
\text { dihy[mg EE/g DW] }\end{array}$ \\
\hline $\begin{array}{c}\text { I. glandulifera } \\
\text { flowers }\end{array}$ & $24.72 \pm 1.91$ & $4.39 \pm 0.81$ & $9.74 \pm 0.93$ & $4.61 \pm 1.34$ & $2.86 \pm 0.73$ \\
\hline $\begin{array}{c}\text { I. glandulifera } \\
\text { leaves }\end{array}$ & $22.84 \pm 2.12$ & $3.84 \pm 0.98$ & $10.06 \pm 1.13$ & $5.34 \pm 0.29$ & $4.72 \pm 1.83$ \\
\hline $\begin{array}{c}\text { I. glandulifera } \\
\text { roots }\end{array}$ & $13.26 \pm 1.68$ & $1.38 \pm 0.11$ & $3.27 \pm 0.48$ & $1.06 \pm 0.48$ & $0.24 \pm 1.17$ \\
\hline I. noli-tangere & $16.53 \pm 0.36$ & $4.67 \pm 1.28$ & $5.13 \pm 0.71$ & $3.20 \pm 0.03$ & $0.87 \pm 0.46$ \\
\hline I. parviflora & $19.34 \pm 0.57$ & $2.09 \pm 0.38$ & $5.82 \pm 0.17$ & $5.17 \pm 1.29$ & $0.42 \pm 0.79$ \\
\hline
\end{tabular}

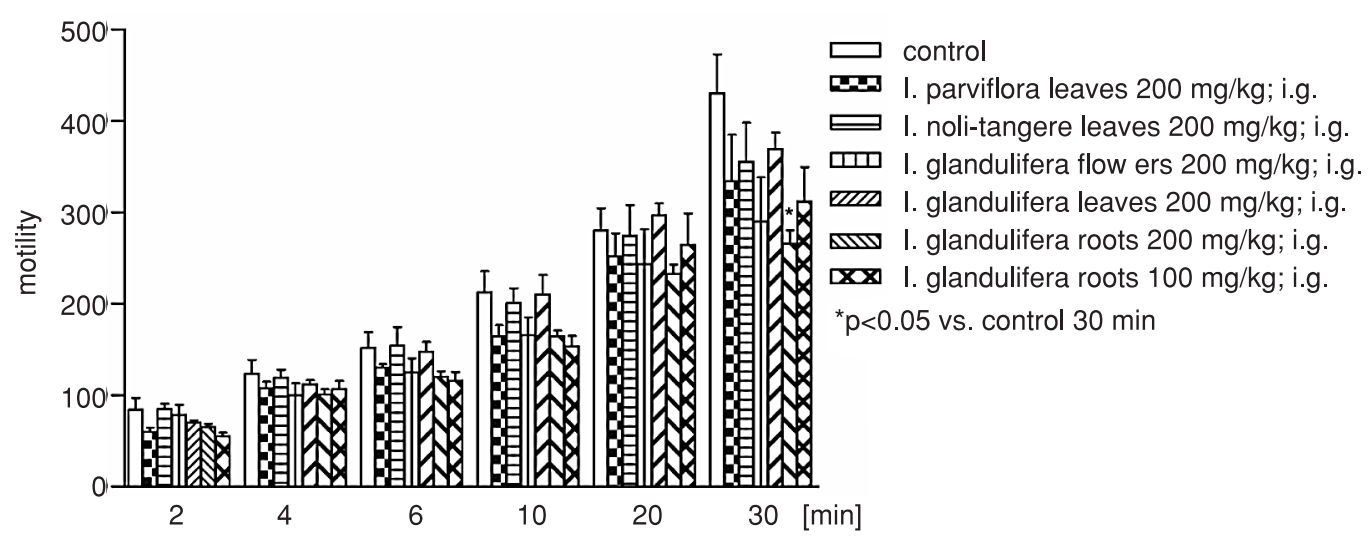

Figure 1. The influence of Impatiens L. extracts on the spontaneous locomotor activity of mice. Extracts were administered i.g. 60 min before the test. Locomotor activity was noted after 2, 4, 6, 10, 20 and $30 \mathrm{~min}$. Data are expressed as mean \pm SEM values. $* \mathrm{p}<0.05 v s$. control group 30 min (Dunnett's test) 
A
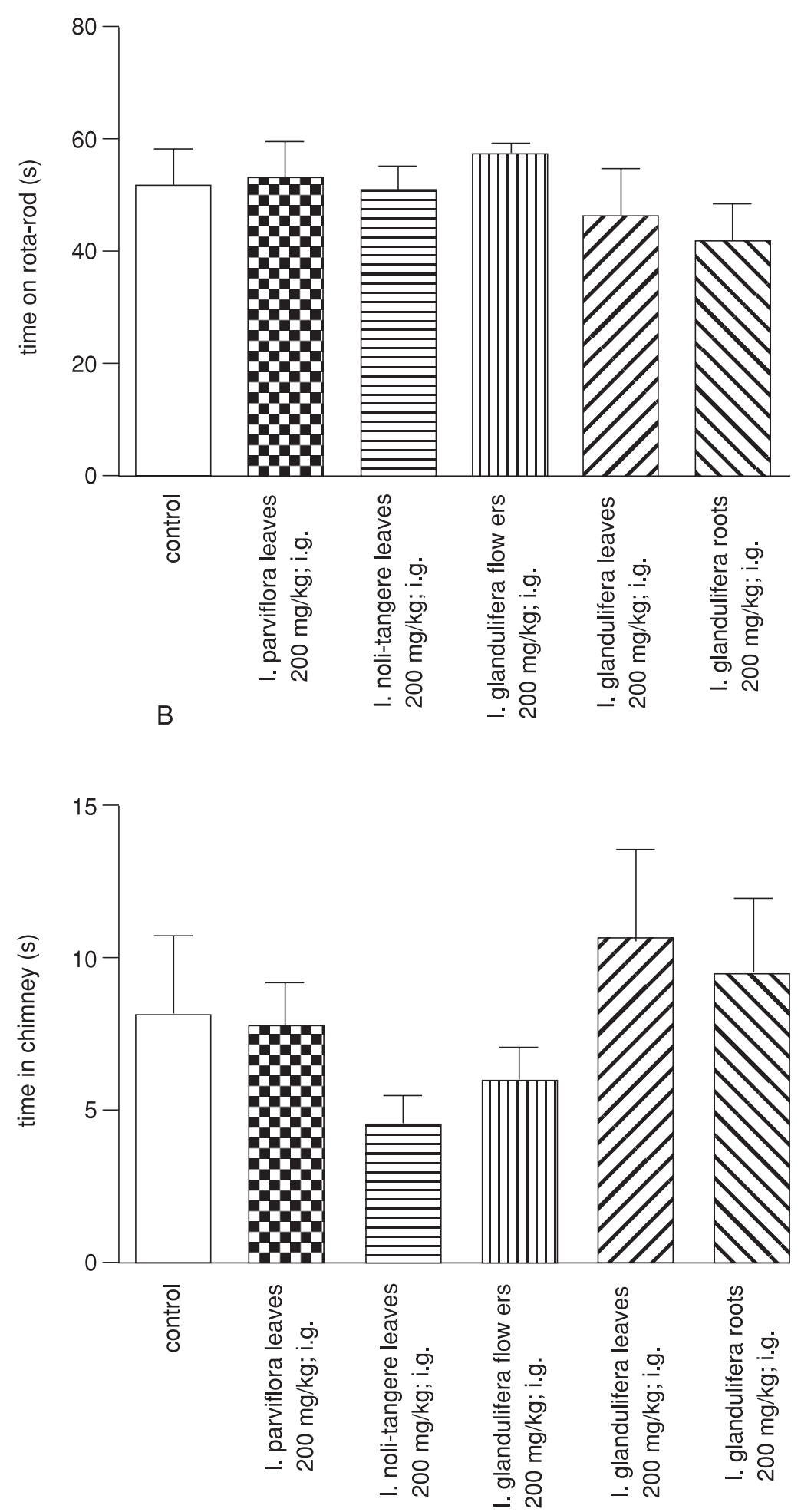

Figure 2. The influence of Impatiens L. extracts on motor coordination in mice evaluated in rota-rod (A) and chimney (B) tests. Extracts were administered i.g. 60 min before the test. Data are expressed as mean \pm SEM values 
decrease in mice body temperature after administration of the extract from I. glandulifera roots in $60(\mathrm{p}$ $<0.001)$, in 90 and $120 \mathrm{~min}(\mathrm{p}<0.01)$ and the extract from $I$. noli-tangere leaves in $60(\mathrm{p}<0.05)$, in $90(\mathrm{p}<0.01)$ and in $120 \mathrm{~min}(\mathrm{p}<0.05)$ (Fig. 3).

\section{Effects of Impatiens L. extracts on nociceptive} reactions and the influence of naloxone on the antinociceptive activity of Impatiens L. extracts in the 'writhing' test in mice

One-way ANOVA showed significant changes in the number of writhing episodes of mice after the administration of tested extracts $\left(\mathrm{F}_{(17,138)}=6.437 ; \mathrm{p}\right.$ $<0.0001)$. Dunnett's post hoc test revealed a significant reduction in the writhing episodes of mice after the administration of the extract from I. parviflora leaves at doses of 200 and $100 \mathrm{mg} / \mathrm{kg}(\mathrm{p}<0.05)$, the extract from I. glandulifera flowers at doses of 200 $(\mathrm{p}<0.001)$ and $100 \mathrm{mg} / \mathrm{kg}(\mathrm{p}<0.01)$, the extract from I. glandulifera leaves at dose of $200(\mathrm{p}<0.01)$, $100(\mathrm{p}<0.01)$ and $50 \mathrm{mg} / \mathrm{kg}(\mathrm{p}<0.05)$, the extract from I. glandulifera roots at doses of 200 ( $\mathrm{p}<$ $0.001), 100(\mathrm{p}<0.01), 50(\mathrm{p}<0.01)$ and $25 \mathrm{mg} / \mathrm{kg}$ $(\mathrm{p}<0.05)$ and a classical non-steroidal analgesic drug, metamizole $(250 \mathrm{mg} / \mathrm{kg}$; i.p., p < 0.001) (Figure 4A). The medium doses of I. parviflora and I. glandulifera extracts (i.e., 100 and $50 \mathrm{mg} / \mathrm{kg}$, respectively) have been chosen for the subsequent experiments. One-way ANOVA showed significant changes in the number of writhing episodes of mice after the administration of the extracts from I. parviflora leaves, I. glandulifera flowers, I. glandulifera leaves and I. glandulifera roots and co-administration of naloxone $(5 \mathrm{mg} / \mathrm{kg})$ with the above-men- tioned extracts $\left(\mathrm{F}_{(8,65)}=5.785 ; \mathrm{p}<0.0001\right)$. Bonferroni's post hoc test revealed that naloxone reversed antinociceptive effect only of the extracts from I. parviflora leaves and I. glandulifera flowers ( $\mathrm{p}<0.05$ and $\mathrm{p}<0.001$, respectively) administered at the dose of $100 \mathrm{mg} / \mathrm{kg}$ (Fig. 4B).

\section{Effects of Impatiens L. extracts on nociceptive reactions in the hot-plate test in mice}

Two-way ANOVA showed statistically significant effects of treatment $\left(\mathrm{F}_{(5,236)}=11.72 ; \mathrm{p}<\right.$ $0.0001)$, time $\left(\mathrm{F}_{(4,236)}=9.67 ; \mathrm{p}<0.0001\right)$ and interactions $\left(\mathrm{F}_{(20,236)}=2.09 ; \mathrm{p}=0.0051\right)$. Bonferroni's post hoc test confirmed that a classical opioid analgesic, morphine (3.3 mg/kg, i.p.) produced a significant effect on the latency to respond to noxious stimulus as compared to control group at $30(\mathrm{p}<$ 0.01), $60(\mathrm{p}<0.05), 90(\mathrm{p}<0.01)$ and $120(\mathrm{p}<0.01)$ min of measurement. Extract from $I$. parviflora leaves $(100 \mathrm{mg} / \mathrm{kg})$ significantly increased the reaction time to the thermal stimulus in $60(\mathrm{p}<0.01)$; 90 $(\mathrm{p}<0.05)$ and $120(\mathrm{p}<0.001) \mathrm{min}$. Extract from $I$. glandulifera flowers significantly increased the reaction time to the thermal stimulus in $90(\mathrm{p}<0.05)$ and $120(\mathrm{p}<0.01) \mathrm{min}$. Extract from I. glandulifera roots significantly increased the reaction time to the thermal stimulus in $60(\mathrm{p}<0.001) ; 90(\mathrm{p}<0.01)$ and $120(\mathrm{p}<0.001) \min$ (Fig. 5).

\section{Effects of Impatiens L. extracts on anxiety-like performance of mice estimated in the EPM}

One-way ANOVA showed significant changes in time spent in the open arms of the $\operatorname{EPM}\left(\mathrm{F}_{(5,36)}=\right.$ $3.731 ; \mathrm{p}<0.01)$. Dunnett's post hoc test revealed

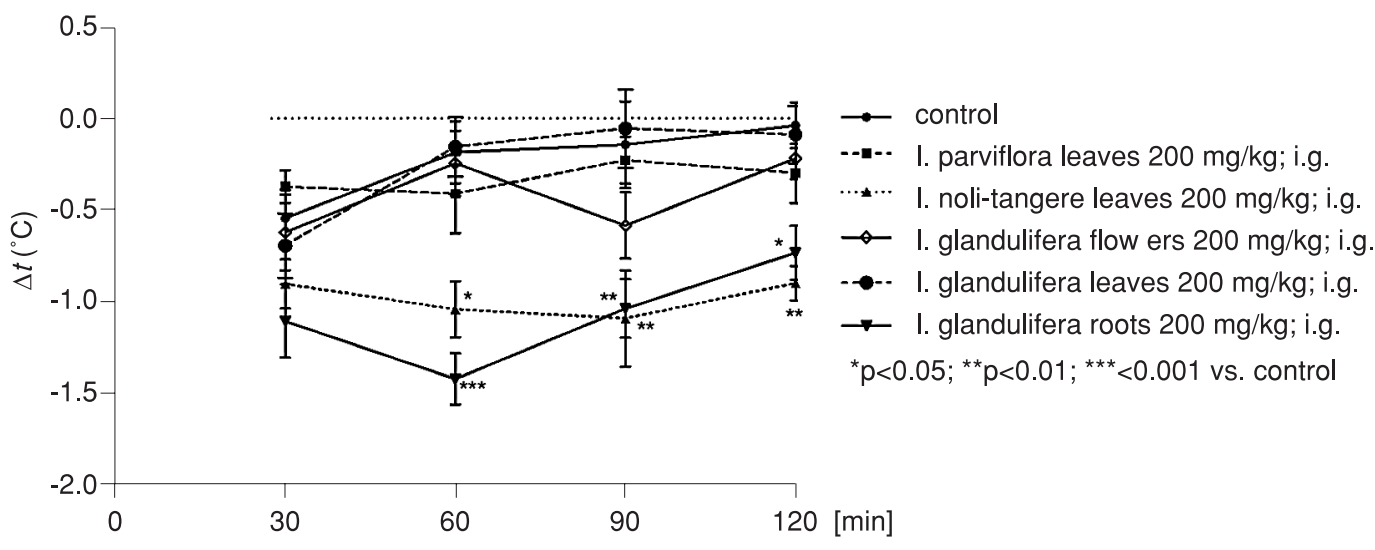

Figure 3. The influence of Impatiens L. extracts on the body temperature in mice. Body temperature was measured during the total period of $180 \mathrm{~min}$ (60 and $30 \mathrm{~min}$ before and 30, 60, 90 and $120 \mathrm{~min}$ after the extracts administration). Data are expressed as mean \pm SEM values. ${ }^{*} \mathrm{p}<0.05 ; * * \mathrm{p}<0.01$ and $* * * \mathrm{p}<0.001 ;$ ss. control group (Bonferroni's test) 
A

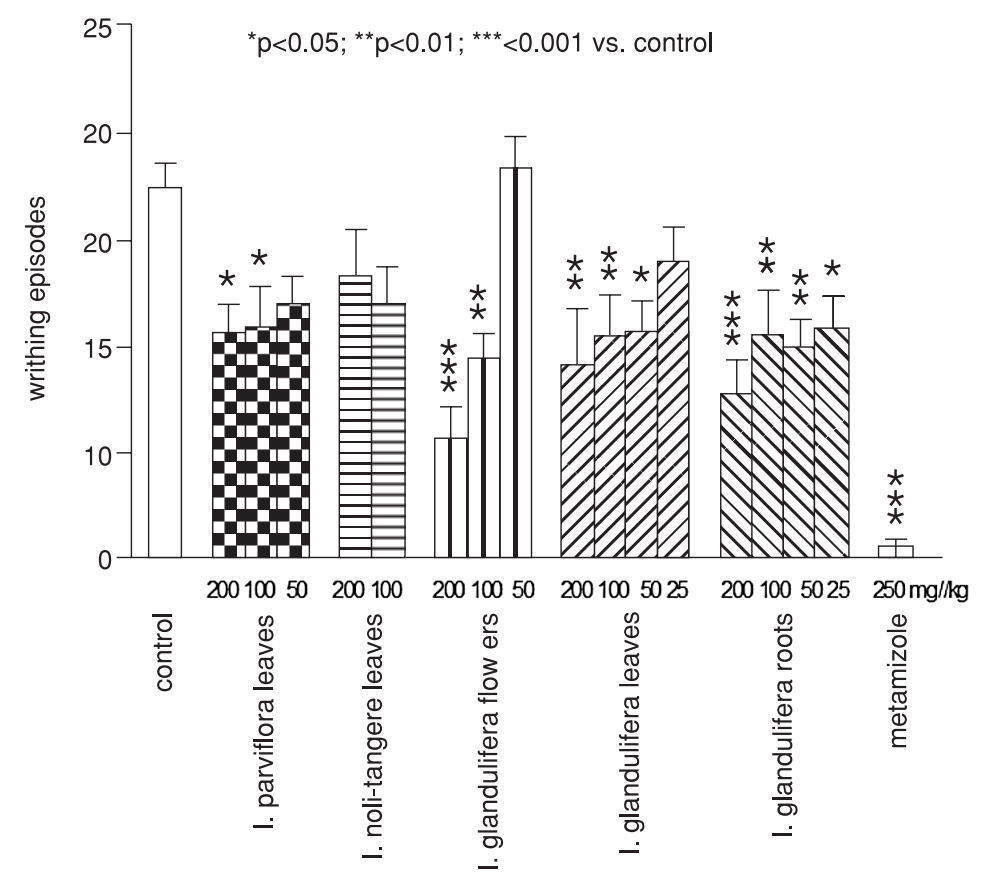

B

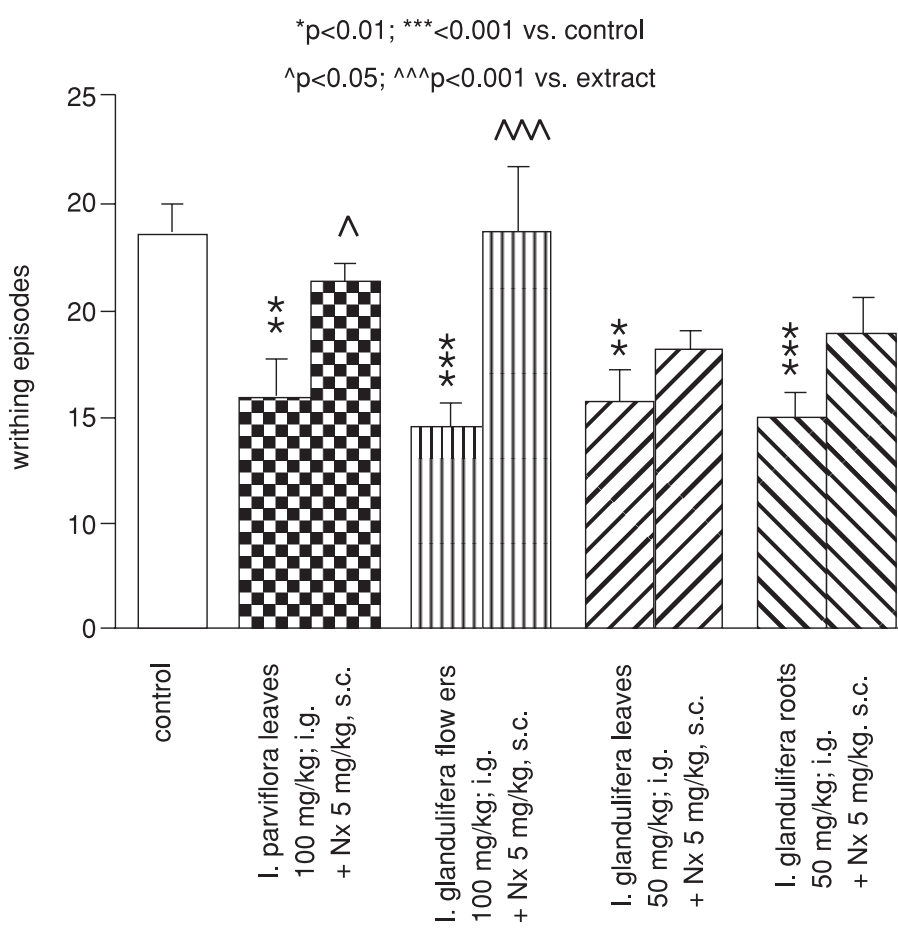

Figure 4. The influence of Impatiens L. extracts and metamizole on nociceptive reactions (A) and the effect of naloxone (Nx; $5 \mathrm{mg} / \mathrm{kg}$, s.c.) on the antinociceptive effects of Impatiens L. extracts (B) assessed in the 'writhing' test in mice. Extracts were administered 60 min, $\mathrm{Nx}$ and metamizole $(250 \mathrm{mg} / \mathrm{kg}$; i.p.) $30 \mathrm{~min}$ and acetic acid $(0.6 \%$ solution) $5 \mathrm{~min}$ before the test. Data are expressed as mean \pm SEM values. ${ }^{*} \mathrm{p}<0.05 ; * * \mathrm{p}<0.01$ and $* * * \mathrm{p}<0.001$ vs. control group; ${ }^{\wedge} \mathrm{p}<0.05$ and ${ }^{\wedge} \wedge \wedge \mathrm{p}<0.001$ vs. appropriate extract (Bonferroni's test) 
that extracts from I. glandulifera flowers, leaves and roots at a dose of $100 \mathrm{mg} / \mathrm{kg}$ produced a substantial increase in time spent in the open arms $(\mathrm{p}<0.05)$ (Fig. 6A).

One-way ANOVA showed significant changes in number of entries into the open arms $\left(\mathrm{F}_{(5,37)}=\right.$ 3.284; $\mathrm{p}<0.05)$. Dunnett's post hoc test revealed that extracts from I. glandulifera leaves and roots at a dose of $100 \mathrm{mg} / \mathrm{kg}$ produced a substantial increase in the number of entries into the open arms $(\mathrm{p}<0.01$ and $\mathrm{p}<0.05$, respectively) (Fig. 6B).

One-way ANOVA showed no significant changes in the total number of entries into both arms (Fig. 6C).

\section{DISCUSSION}

The major findings of the present work are that (1) the $\mathrm{ED}_{50}$ of all tested Impatiens L. extracts is more than $2 \mathrm{~g} / \mathrm{kg}$ in mice; (2) oral (i.g.) administration of Impatiens L. extracts at the dose of $0.1 \mathrm{ED}_{50}$ $(200 \mathrm{mg} / \mathrm{kg})$ did not disturb motility or motor coordination of mice; (3) the extracts from I. noli-tangere leaves and I. glandulifera roots, both at 200 $\mathrm{mg} / \mathrm{kg}$, i.g., decreased body temperature of mice; (4) oral administration of Impatiens L. extracts (except from I. noli-tangere) significantly inhibited the acetic acid-induced abdominal constriction; (5) the antinociceptive effect of $I$. parviflora leaves and $I$. glandulifera flowers had been effectively antagonized by the use of naloxone suggesting involvement of opioid receptors; (6) oral administration of extracts from I. parviflora, I. glandulifera flowers and roots increased the reaction time to the thermal stimulus in the hot plate test; (7) oral administration of all extracts from I. glandulifera showed anxiolytic effects in the EPM test.

At the beginning of the experiment, the acute toxicity of the extracts was calculated as the $\mathrm{ED}_{50}$, based on the loss of the righting reflex within $24 \mathrm{~h}$, using the up-and-down methods. The results showed that the dose of $2000 \mathrm{mg} / \mathrm{kg}$ of tested extracts did not cause any behavioral changes. Therefore, it can be assumed that Impatiens L. extracts possess low toxicity profile. This value of $\mathrm{ED}_{50}$ was adopted and the regressive doses of $\mathrm{ED}_{50}$ were used for further studies.

Further results of the pharmacological investigations showed that the examined extracts (except form I. glandulifera roots) did not exert any influence on locomotor activity of animals, at the dose of $0.1 \mathrm{ED}_{50}$, i.e., the starting dose. Whereas, oral administration of I. glandulifera roots extract (200 $\mathrm{mg} / \mathrm{kg}$ ) showed statistically significant decrease in motility of mice, $30 \mathrm{~min}$ after the beginning of the measurement. Thus, at the lower dose of $100 \mathrm{mg} / \mathrm{kg}$, this extract did not affect locomotion of animals. It can be supposed that I. glandulifera roots extract has a weak depressive effect on the CNS. The measurement of motor activity is a standard behavioral assay for testing the sedative effects of drugs (22). A druginduced decrease in the animal's spontaneous activity is defined by Katzung et al. (35) as sedation.

It is worth noting that none of the extracts, at the highest used dose - $0.1 \mathrm{ED}_{50}(200 \mathrm{mg} / \mathrm{kg})$, caused coordination impairments or myorelaxation as measured in the rota-rod and chimney tests. These results seem to suggest that the tested extracts are not neurotoxic, thus prompting further studies to

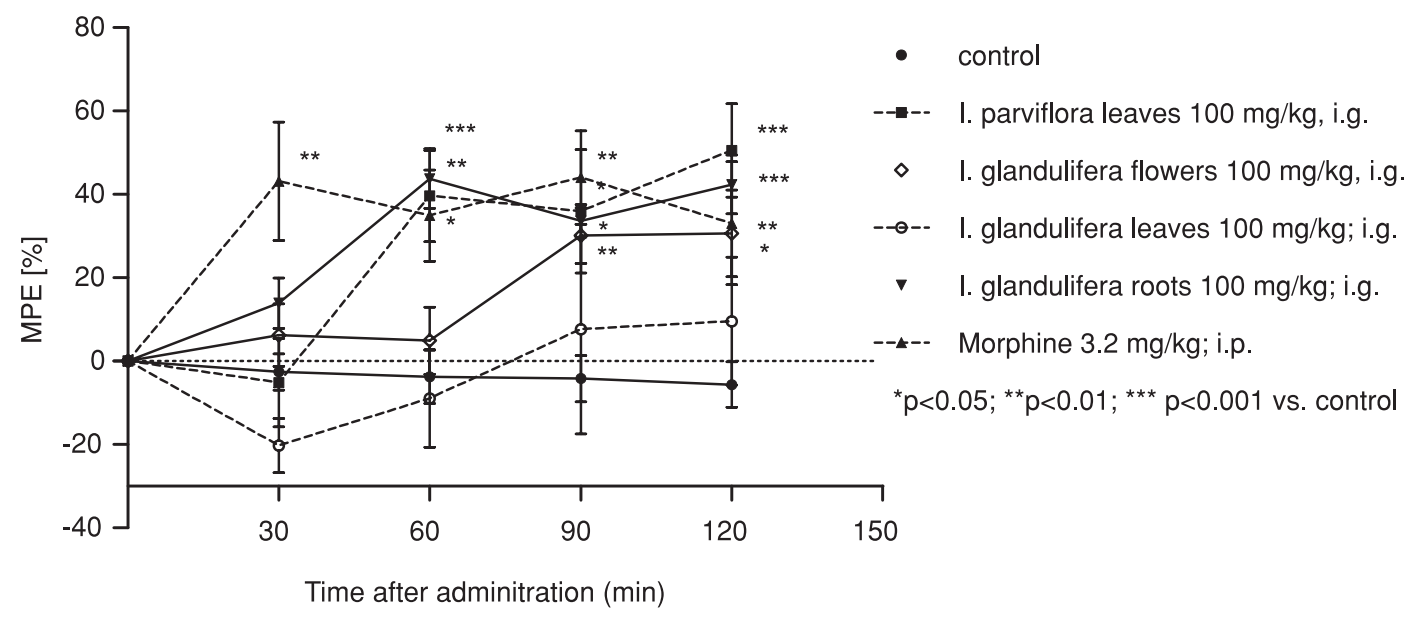

Figure 5. The influence of Impatiens L. extracts and morphine $(3.2 \mathrm{mg} / \mathrm{kg}$, i.p.) on nociceptive reactions assessed in the hot plate test in mice. Nociceptive reactions were measured during the total period of $120 \mathrm{~min}$ (30, 60, 90 and $120 \mathrm{~min}$ after the extracts and morphine administration). Data are expressed as mean \pm SEM values. $* \mathrm{p}<0.05 ; * * \mathrm{p}<0.01$ and $* * * \mathrm{p}<0.001$ vs. control group (Bonferroni's test) 


\section{A}

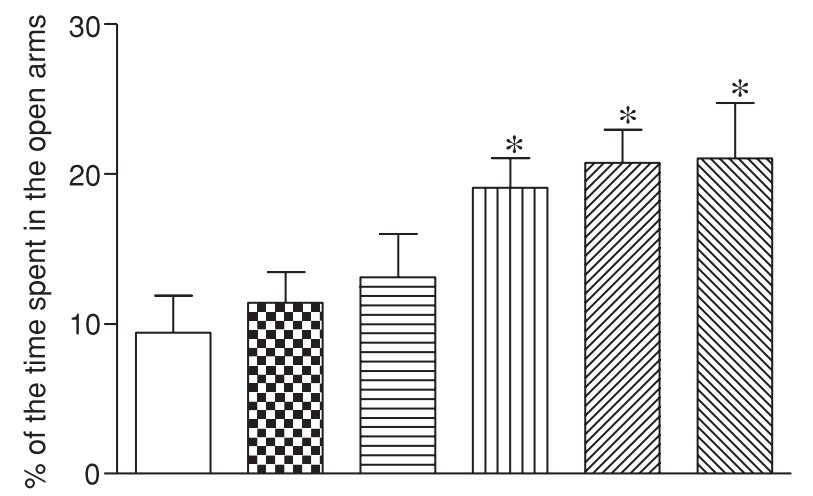

$\square$ control

I. parviflora leaves 100 mg/kg; i.g.

$\Longleftarrow$ I. noli-tangere leaves 100 mg/kg; i.g. I. glandulifera flow ers $100 \mathrm{mg} / \mathrm{kg} ; \mathrm{i.g}$. एسय I. glandulifera leaves $100 \mathrm{mg} / \mathrm{kg} ; \mathrm{i} . \mathrm{g}$. I. glandulifera roots $100 \mathrm{mg} / \mathrm{kg}$; i.g. ${ }^{*} p<0.05 ;{ }^{* *} p<0.01$ vs. control

B

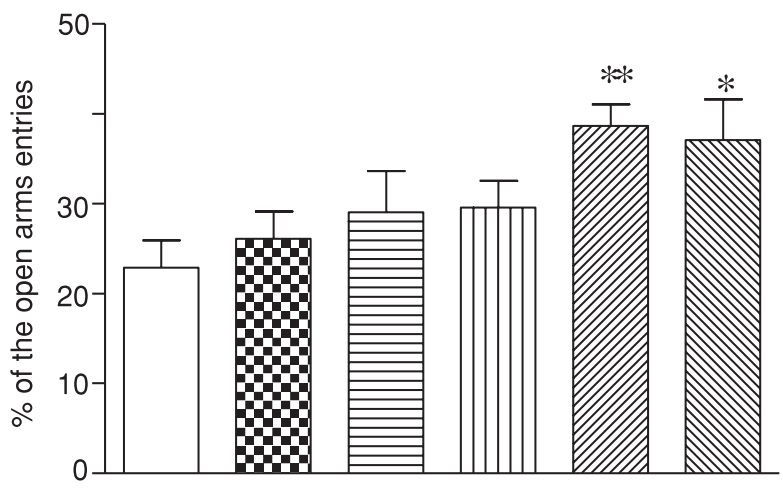

C

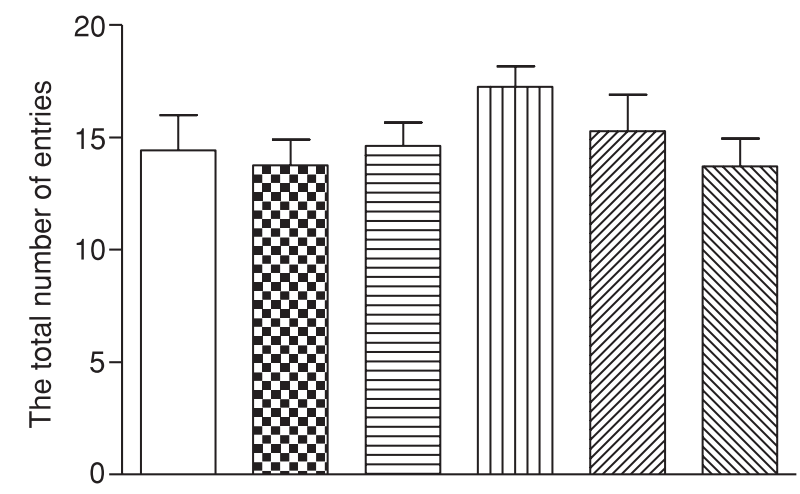

Figure 6. The influence of Impatiens L. extracts on anxiety-like performance of mice estimated in the EPM. Data are expressed as mean \pm SEM values. ${ }^{*} \mathrm{p}<0.05$ and ${ }^{* *} \mathrm{p}<0.01 \mathrm{vs}$. control group (Dunnett's test) 
confirm their safety and therapeutic efficacy. What is more, the lack of coordination disturbances and muscle relaxant potency are important features, because their presence can affect reliability of the other behavioral performances (22).

In the present experiments, the body temperature of normothermic mice was also tested after the oral administration of the extracts, every half an hour up to $2 \mathrm{~h}$. This measurement is a part of preliminary behavioral investigations (22). The extracts from I. noli-tangere leaves and I. glandulifera roots, both at a dose of $200 \mathrm{mg} / \mathrm{kg}$, caused a significant decrease in the body temperature of mice up to 120 min of the experiment. The most important role in the regulation of body temperature plays hypothalamic receptors whose action mainly depends on serotonin. According to the literature data, the hypothermic effect may be caused by substances which are agonists of serotonin 5-HT1A receptor as well as 5HT2A receptor antagonists $(36,37)$, and we can suggest that these mechanisms of action can be also involved in the effects of extract under study.

An important observation of the presented study was the antinociception and/or anti-inflammation induced by the tested extracts, excluding I. nolitangere. Obtained results demonstrated that an oral administration of Impatiens L. extracts elicited a potent and dose-dependent antinociceptive and/or anti-inflammatory effect in acetic acid-induced writhing test. The writhing procedure is a chemicalinduced nociception method, useful for sifting compounds the pharmacological features of which are unknown. This test is based on chemical stimulation, induced by an i.p. administration of agents that irritate serous membranes and provoke characteristic abdominal contractions. The writhing test lacks specificity but is very sensitive, predictive and the closest in its nature to clinical pain. It is a model of visceral or peritoneal pain, although it does not preclude central mechanisms of antinociception (32). The specificity of the writhing test can be improved by undertaking a preliminary rota-rod test to detect and eliminate substances that alter the motor performance of animals. In our study, it was estimated that none of the examined extracts impaired motor coordination in mice, as already mentioned. A strong impact on mice behavior in that test was observed for I. glandulifera leaves and roots extracts at a wide range of doses, up to 0.025 (for leaves) and up to $0.0125 \mathrm{ED}_{50}$ (for roots). At the highest doses, i.e., $0.1 \mathrm{ED}_{50}(200 \mathrm{mg} / \mathrm{kg})$ of I. glandulifera flowers and roots extracts showed a significant reduction in writhing episodes which were comparable to the action of the reference drug - metamizole (250 $\mathrm{mg} / \mathrm{kg}$ ), a non-steroidal analgesic agent. It is known that i.p administration of the acetic acid causes an increase in eicosanoids biosynthesis i.e., cyclooxygenase, lipoxygenase, and prostaglandins activity, which are associated with the development of inflammatory pain and abdominal constriction (38). It has been reported that the phytochemicals, particularly the phenolics and flavonoids could be responsible for the anti-inflammatory activity which was shown in the writhing test $(38,39)$. An important anti-inflammatory feature of flavonoids is the capability to inhibit eicosanoids biosynthesis (40). This data is consistent with our previous results showing that members of the genus Impatiens, in particular Impatiens glandulifera, and Impatiens parviflora, contain significant amounts of phenolic acids and flavonoids (18). Our results revealed the presence of eriodictyol-di-O-hexoside, eriodictyol- $O$-hexoside, quercetin-3- $O$-galactoside (hyperoside), quercetin3-O-glucoside (isoquercitrin), kaempferol-3-O-glucoside (astragalin), eriodictyol, and kaempferol in methanolic extracts from the leaves of I. glandulifera, and hyperoside, isoquercitrin, quercetin- $O$-malonylhexoside, astragalin, and kaempferol- $O$-malonylhexoside in the leaves of $I$. parviflora, and hyperoside, isoquercitrin, quercetin- $O$-malonylhexoside, and astragalin in the leaves of $I$. noli-tangere. Moreover, a great amount of protocatechuic, vanillic, trans-p-coumaric and a 3-hydroxycinnamic acid was observed in these three species (20). Some of the identified in Impatiens species flavonoids, such as kaempferol and quercetin, and its glycosides, possesses proven anxiolytic activities. Grundmann et al. (41) tested kaempferol for its potential anxiolytic activity in mice. Kaempferol exhibited significant activities in the percentage time spent on open arms after oral administration in concentrations above $0.01 \mathrm{mg} / \mathrm{kg}$, and the observed activity decreased at higher doses. An anxiolytic-like effect was also reported for pure quercetin by oral and intranasal way in rats $(42,43)$.

Because the writhing test is not a specific method and it cannot be precluded the central mechanism of tested compounds which are active in this test, naloxone was used to antagonize the effects. This nonselective opioid antagonist reversed the action only of I. parviflora leaves and I. glandulifera flowers observed in the writhing test. These results seem to indicate a possible interaction with the opioid system (44). Additionally, an oral administration of extracts from I. glandulifera flowers and roots at a dose of $100 \mathrm{mg} / \mathrm{kg}$ significantly increased the latency period to the thermal stimuli in the hot-plate test suggesting the central antinociceptive activity of 
these extracts. The hot-plate procedure demonstrates the supraspinal reflex mediated by opioid receptors (33). The antinociceptive activity and the direct involvement of the activation of opioid receptors in this effect have been already reported for flowers extracts from another Impatiens species - I. balsamina (9).

Whereas the reduction in the writhing episodes caused by $I$. glandulifera leaves and roots extracts was not antagonized by naloxone, it can be suggested rather a peripheral mechanism involved in these effects. On the other hand, it was shown that the antinociceptive effect of polyphenolic compounds, e.g., vanillic acid occurs by a mechanism partly dependent upon the opioid system, while the antiinflammatory action was manifested in inflammatory processes dependent on the vanillic acid inhibition of cytokines (45).

In the present study, the potential anxiolytic profile of the investigated extracts was assessed in the EPM. All extracts from I. glandulifera showed anxiolytic-like activity, increasing, in a statistically significant manner, the time spent in the open arms of the EPM and the number of entries into open arms. It is worth to note that these extracts did not influence the total number of entries which means that they did not change locomotor activity of mice. Regulation of anxiolytic activity depends on different neurotransmitters (e.g., the gamma-aminobutyric acid, dopamine or serotonin) (31). Thus, further chemical studies are required to elucidate the precise molecular mechanisms responsible for the activity of the I. glandulifera extracts.

Taking together, it seems that the extracts obtained from I. glandulifera (leaves, flowers or roots) are more biologically active than extracts from leaves of I. parviflora and I. noli-tangere. All these extracts possess low toxicity and have insignificant influence on the based neuropharmacological activities, i.e., locomotion and motor coordination.

The presented results provide some preliminary estimations, thus, need to be further extended for closer identification and deeper understanding of the entire pharmacological profile of the examined extracts.

\section{CONCLUSIONS}

In conclusion, the results of the present study indicated that $I$. glandulifera extracts caused strong reduction in the number of writhing episodes. The effects of hydroethanolic extracts from flowers, leaves and roots of I. glandulifera seem to be medi- ated by the peripheral inflammatory mediators such as cyclooxygenase-2, while the effect of I. glandulifera flowers can be also associated with the opioid receptor. These results justify the use of the plant in folk medicine in the treatment of mental tension and different painful conditions. It will be of considerable interest for the future to isolate the bioactive compound(s) and elucidate the precise molecular mechanisms responsible for the pharmacological activities of the plant.

\section{Acknowledgments}

The study was partially supported by statutory funds provided by the Polish Ministry of Science and Higher Education for Medical University of Lublin, Poland (G. Biała).

\section{Conflicts of interest}

The authors declare no conflict of interest.

\section{REFERENCES}

1. https://www.iasp-pain.org/Taxonomy (accessed on 19.11.2017).

2. Crofford L.J.: Nat. Rev. Rheumatol. 6, 191 (2010).

3. Pan S.Y., Zhou S.Z., Gao S.H., Yu Z.L., Zhang S.F. et al:. Evid. Based Complement. Alternat. Med. (2013) doi:10.1155/2013/627375.

4. Grey-Wilson C.: Impatiens of Africa, CRC Press, Rotterdam, Netherlands, 1980.

5. Pyšek P., Prach K.: Biol. Conserv. 74, 41 (1995).

6. Weber E.: Invasive Plant Species of the World: A Reference Guide to Environmental Weeds, CABI Publishing, Wallingford, Oxon, UK, 2003.

7. Vrchotová N., Šerá B., Krejčová J.: Plant Soil. Environ. 57, 57 (2011).

8. Tokarska-Guzik B., Węgrzynek B., Urbisz A., Urbisz A., Nowak T., Bzdęga K.: Biodivers. Res. Conserv. 19, 33 (2010).

9. Imam M.Z., Nahar N., Akter S., Rana M.S.: J. Ethnopharmacol. 142, 804 (2012).

10. Kumar M., Paul Y., Anand V.K.: Ethnobotanical. Leaflets. 13, 1240 (2009).

11. Wang Y.C., Wu D.C., Liao J.J., Wu C.H., Li W.Y., Weng B.C.: Am. J. Chin. Med. 37, 713 (2009).

12. Ishiguro K., Fukumoto H., Murashima T., Kuriyama M., Semma M., Isoi K.: Phytother. Res. 6, 112 (1992). 
13. Yang X., Summerhurst D.K., Koval S.F., Ficker C., Smith F.L., Bernards M.A.: Phytother. Res. 15, 676 (2001).

14. Pavela R., Vrchotová N., Šerá B.: J. Biopest. 2, 48 (2009).

15. Thaler K., Kaminski A., Chapman A., Langley T., Gartlehner G.: BMC Complement. Altern. Med. 9, 16 (2009).

16. Bourbonnais-Spear N., Awad R., Merali Z., Maquin P., Cal V., Arnason J.T. J. Ethnopharmacol. 109, 380 (2007).

17. Kujawska M.: Etnobiologia Polska. 3, 31 (2013).

18. Szewczyk K., Zidorn C., Biernasiuk A., Komsta Ł., Granica S.: Ind. Crops. Prod. 86, 262 (2016a).

19. Miazga-Karska M., Szewczyk K., Klimek K., Ginalska G.: Acta Pol. Pharm. 74, 710 (2017).

20. Szewczyk K., Olech M.: Phytochem. Lett. 20, 322 (2017).

21. Szewczyk K., Kalemba D., Komsta Ł., Nowak R.: Molecules 21, 1162 (2016).

22. Vogel H.G.: Psychotropic and neurotropic activity, in Drug Discovery and Evaluation: Pharmacological Assays, Vogel H., Ed., pp. 565-693, Springer-Verlag, Berlin Heidelberg 2008.

23. Singleton V.L., Rossi J.A.Jr.: Am. J. Enol. Vitic. 16, 144 (1965).

24. Lamaison J.L.C., Carret A.: Plantes Médicinales Phytothérapie 25, 12 (1990).

25. Polish Pharmacopoeia IX, PTFarm. Polish Pharmaceutical Society, Warszawa, Poland 2011; p. 150.

26. Popova M., Silici S., Kaftanoglu O., Bankova V.: Phytomedicine 12, 221 (2005).

27. Salas A.L., Alberto M.R., Zampini I.C., Cuello A.S., Maldonado L., Ríos J.L. et al.: Phytomedicine 23, 27 (2016).

28. Pontis J.A., da Costa L.A.M.A., da Silva S.J.R., Flach A.: Food. Sci. Technol. (Campinas). 34, 69 (2014).

29. Directive 2010/63/EU of the European Parliament and of the Council. Official Journal of the European Union. Retrieved August 2, 2016.

30. OECD. 425: Acute Oral Toxicity: Up-andDown Procedure. OECD Guidelines for the
Testing of Chemicals. Paris: OECD Publishing; 2008.

31. Fiorino F., Ciano A., Magli E., Severino B., Corvino A., Perissutti E. et al.: Eur. J. Med. Chem. 110, 133 (2016).

32. Le Bars D., Gozariu M., Cadden S.W.: Pharmacol. Rev. 53, 597 (2001).

33. Kotlińska J.H., Gibuła-Bruzda E., Suder P., Wasielak M., Bray L., Raoof H. et al.: Peptides. 36, 17 (2012).

34. Lister R.G.: Psychopharmacology (Berl.). 92, 180 (1987).

35. Katzung B.G., Masters S.B., Trevor A.J.: Basic \& Clinical Pharmacology, $12^{\text {th }}$ ed. The McGraw-Hill Companies, Inc, USA, 2012.

36. Adell A., Bigg T.A., Myers R.D.: Neuropharmacology. 35, 1101 (1996)

37. Kędzierska E., Orzelska J., Perković I., Knežević D., Fidecka S. et al.: Fundam. Clin. Pharmacol. 30, 58 (2016).

38. Khatun A., Rahman M., Rahman M.M., Hossain H., Jahan I.A., Nesa M.L.: Front Pharmacol. 7, 176 (2016).

39. Morucci F., Lopez P., Mino J., Ferraro G., Gorzalczany S.: J. Ethnopharmacol. 142, 401 (2012).

40. Sankari S.L., Babu N.A., Rani V., Priyadharsini C., Masthan K.M.: J. Pharm. Bioallied. Sci. 6, S26 (2014).

41. Grundmann O., Nakajima J.I., Kamata K., Seo S., Butterweck V.: Phytomedicine. 16, 295 (2009).

42. Aguirre-Hernández E., González-Trujano E., Martínez A.L., Moreno J., Kite G. et al.: J. Ethnopharmacol. 127, 91 (2010).

43. Priprem A., Watanatorn J., Sutthiparinyanont S., Phachonpai W., Muchimapura S.: Nanomedicine 4, 70 (2008).

44. Talarek S., Fidecka S.: Pol. J. Pharmacol. 54, 27 (2002).

45. Leal L.K., Pierdoná T.M., Góes J.G., Fonsęca K.S., Canuto K.M., Silveira E.R. et al.: Phytomedicine. 18, 230 (2011).

Received: 08.11.2017 